\title{
Economic Valuation as an Instrument to Determine The Management Strategy of Baros Mangrove Forest, Bantul, Yogyakarta, Indonesia
}

\author{
Irawan Waluyo Jati ${ }^{1, *}$, Rudhi Pribadi $^{2}$ \\ ${ }^{1}$ Master Program of Environmental Science, School of Postgraduate Studies, Diponegoro University, Semarang - Indonesia \\ ${ }^{2}$ Department of Marine Science, Faculty of Fisheries and Marine Science, Diponegoro University, Semarang - Indonesia
}

\begin{abstract}
The Baros mangrove forest in Bantul Regency is now beginning to develop. Many government and private sectors programs are rolled out to support its development. The development of the Baros mangrove forest must be in accordance with the rules of conservation so that it will not damage the mangrove ecosystem. Mangrove forest has high economical and ecological value but is very vulnerable if lack of wisdom in maintaining, preserving and managing them. The involvement of government and other stakeholders are essential in determining management policies. Unawareness of society and the government to the importance of mangrove ecosystem can cause development of it becomes uncontrolled, consequently can destroy it. Mangrove forests are an important natural resource in coastal environments, and have three main functions: physical, biological, and economic functions. To quantify the functions of mangrove forests as the basis to determine the policy is required a research instrument called economic valuation. The approach of this study is the literature review from various studies before to perceive the influence of economic valuation in determining the management strategy of Baros mangrove forest in Bantul Regency, Yogyakarta, Indonesia.
\end{abstract}

\section{Introduction}

Mangrove is one of the rare ecosystems, because the area is only $2 \%$ of the earth's surface. Indonesia is the largest mangrove ecosystem in the world [1]. Mangroves as an ecosystem have unique properties and forms and have diverse functions and benefits for humans and other living things [2].

The large potential of mangrove forests encourages excessive resource exploitation that can threaten its sustainability. Pramudji mentions that mangrove damage is not only caused by natural processes, but also due to human activities [3]. The existence of mangrove forest exploitation for the fulfilment of excessive human needs and ignoring the rules of conservation will be able to damage the mangrove itself. The ignorance of the community and the government of the importance of mangrove forest ecosystem causes development in the framework of mangrove forest area development becomes uncontrolled so that it will become damaged [4].

The existence of mangrove forest spread in Indonesia, one of them is in Baros Hamlet, Village of Tirtohargo,Kretek sub district, Bantul Regency. The mangrove ecosystem is precisely in the estuary / encounter between the southern sea and the mouth of the Opak River. The Baros mangrove forest is a mangrove conservation area that has the appeal of biological natural resources, geological formations, and / or natural phenomena that can be developed for the benefit of the development of science, research, education and awareness raising of the conservation of biological natural resources, marine tourism and recreation. Baros mangrove forest became one of the coastal and marine ecosystems that are potential for improving the welfare of the people of Baros Hamlet in terms of economic, social and environmental.

Based on interviews with the manager that the current Baros mangrove conditions as a special interest attraction has grown. The existence of programs from the government both central and regional as well as the private sector in order to develop the Baros mangrove area would need new spaces. Programs Development of mangrove areas without regard to ecological function will actually damage the existence of mangrove and this will cause problems in the future. [5] mentions that the destruction of mangrove forest one of them caused by the mistake of government policy.

Mangrove forests have high economic and ecological value but are very vulnerable to damage if not prudent in maintaining, preserving and managing them [6]. The damage usually experienced by mangrove is caused by human activities directly in the utilization of mangrove forest ecosystem. To avoid these problems, it is necessary to assess the utilization of mangrove forests, not only economic benefits but also the consideration of

* Corresponding author:irawan.bantul@,gmail.com 
ecological benefits that can become a reference in the mangrove forest management strategy.

This study aims to determine the total economic value of mangrove forests and the implementation of sustainable mangrove management strategies in the mangrove area of Baros, Tirtohargo, Kretek, Bantul.

\section{Methods}

\subsection{Data collection technique}

This research is done by using data collection method which divided into secondary data and literature review. Secondary data were collected through document review and documentation of activities related to Baros mangrove forests. While the literature review comes from similar studies and research related to Baros mangrove forest. The analytical methods used are quantitative and qualitative methods, which are then described to explain the total economic value and strategy of Baros mangrove forest management.

\subsection{Analysis technique}

The economic assessment of all the benefits of natural resources of mangrove forest refers to the concept of natural or environmental value according to [7] [8]. The economic values contained in a natural resource, both useful and functional, must be taken into account in formulating management policies so that their allocations and alternative uses can be properly determined and targeted [9]. The formulation is as follows:

$\mathrm{TEV}=\mathrm{TUV}+\mathrm{NUV}=(\mathrm{TDUV}+\mathrm{TIUV}+\mathrm{OV})$

Where :

TEV : Total Economic Value

TUV : Use Value

NUV : Non Use Value

TDUV : Total Direct Use Value

TIUV :Indirect Use Value

OV : Option Value

\section{Results and discussion}

This research was conducted in Baros mangrove forest area, Tirtohargo village, Kretek subdistrict, Bantul district located at $110^{\circ} 17$ '9199 "BT and $8^{\circ} 0^{\prime} 48.066^{\prime \prime}$ LS. The location of this study was chosen because it is the only mangrove forest in Bantul district and is one of the icons of tourism and conservation. The location of the research can be seen in Figure 1.

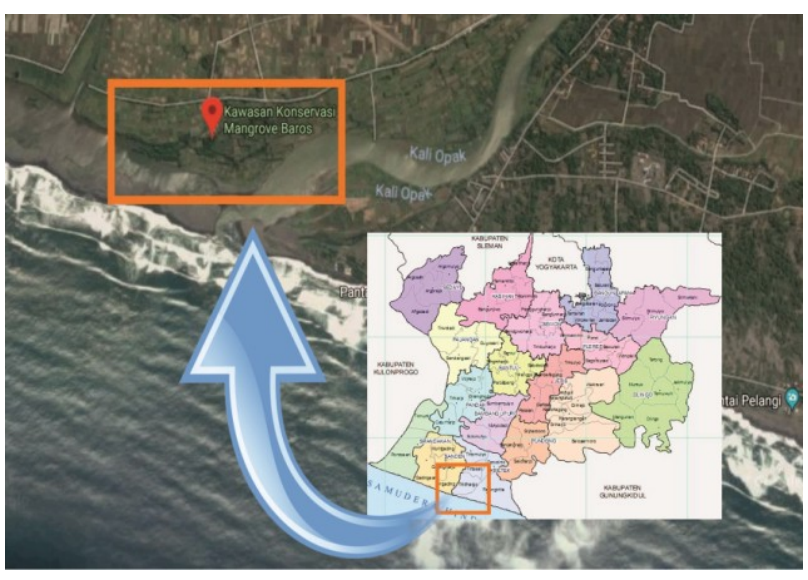

Fig. 1. Map of Mangrove Baros Forest Area

\subsection{Mangrove forest ecosystem condition}

The mangrove forest ecosystem in Baros Village is managed by Pemuda Pemudi Baros Family (KP2B) since 2003. Mangrove planting is done in Sultan Ground land in Opak River estuary of $25 \mathrm{Ha}$. Until now the wellgrown Mangrove is $3-4 \mathrm{Ha}$. The type includes Avicennia sp. 60\%, Rhizhopora sp. 20\%, Brugueira sp. $10 \%$, and Nipah $10 \%$ [10]. Composition of mangrove species in Baros mangrove forest can be seen in Figure 2. Based on inventory conducted by [11] in Baros mangrove area recorded four (4) mangrove species: Avicennia sp., Rhizophora sp., Bruguiera sp., And Nypa frutican.

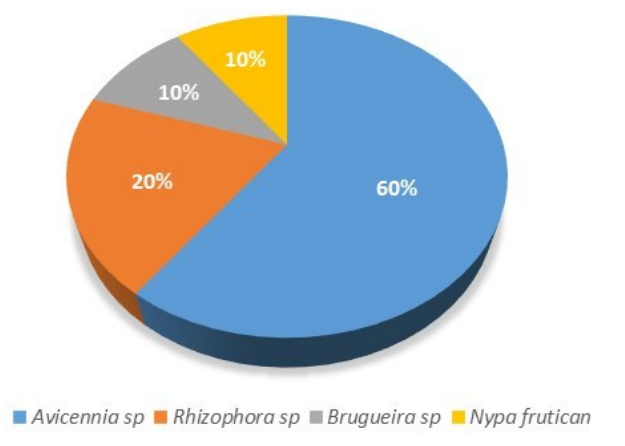

Fig 2. Composition of mangrove species in Baros mangrove forest

In an effort to protect and conserve biodiversity in the Baros mangrove ecosystem, the Local Government through the Regent of Bantul Regency on April 28, 2014 establishes Baros mangrove area as a Mangrove Conservation Area through the Decree of Bupati Bantul Number 284 Year 2014 on Coastal Reserve Conservation Area. Zoning in the Baros mangrove conservation area consists of three zones, namely core zone (10 ha), other zones (94 ha) and limited utilization zones (28 ha) [12]. Map of reserve area of conservation of mangrove coastal park of Bantul Regency can be seen in Figure 3. 


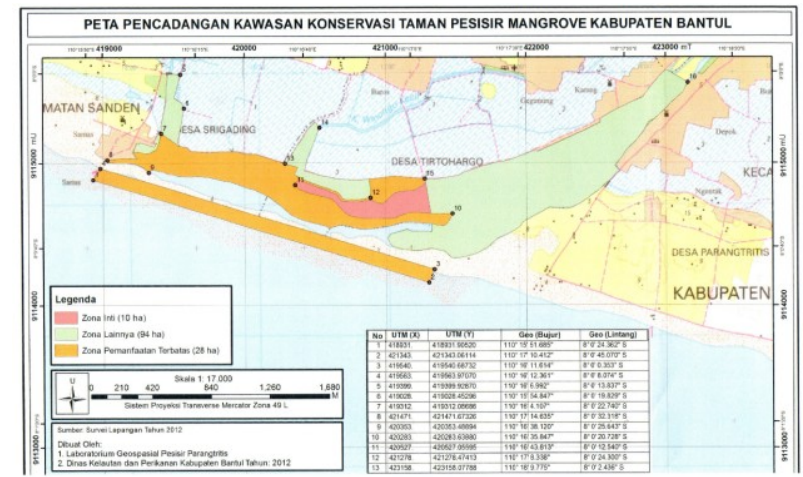

Fig. 3. Map of reserve area of conservation of mangrove coastal park Bantul Regency

\subsection{The value of economic benefits of baros mangrove forest}

\subsubsection{Direct use value}

a. Fisheries

Vegetation Mangrove is a convenient habitat for crabs, is a place to live plankton as a source of food for crabs, shrimp and fish. So many fishermen who get sea products around the Mangrove forest. Communities around the Baros mangrove forest get a lot of benefits, one of them is fishery. Based on research conducted by [13] that the fishery products obtained in the area of Baros mangrove forest such as Scylla sp., Mugil sp., Macrones sp. And Oreochromis. The cost of fishing is Rp. 20.467.542, - / year with total revenue Rp. 100.716.000, - / year. The profit earned by fishermen is Rp. 80.248.458, - / year.

b. Mangrove seeds

Making mangrove seedlings ready for planting (Avicenia) is able to create jobs for group members. Currently, the types of mangrove seeds made by KP2B are sold to those in need. [10] states that the mangrove seedlings per year reaches 5,200 Avicenia $s p$ mangrove seedlings sold at $\mathrm{Rp} 2.000,00$ / seedlings, the total value of Avicenia $s p$ mangrove seedlings is Rp 10.400.000, - / year.

\subsubsection{Indirect use value}

\section{Coastal Protection (Breakwater)}

Mangrove is one of the unique and unique ecosystems that can protect the coast from abrasion [14]. The indirect benefits of mangrove forests as abrasion holder are diminized through replacement cost with the construction of breakwater buildings. Based on the research [6] The cost of breakwater construction for a distance of $1 \mathrm{~m}$ with endurance for 10 years is $\mathrm{Rp}$. 21.986.700, - and the length of Baros mangrove forest is $500 \mathrm{~m}$, the function value is $\mathrm{Rp} 10,993,350,000,-/ 10$ years or $\operatorname{Rp~1,099,335,000~/~year.~}$

\subsubsection{Option value}

The benefit of choice is a value that indicates a person's willingness to pay in order to preserve the mangrove ecosystem for future use. This value is approached with reference to the biodiversity value of mangrove forests in Indonesia. As a reference value of biodiversity in Indonesia used the results of research from [7] that is US $\$ 1500 / \mathrm{km}^{2} /$ year. The area of Baros mangrove land used is referring to the Decree of the Regent of Bantul Number 284 of 2014 on the Reserve of Coastal Conservation Area. Zoning in the Baros mangrove conservation area is the core zone (10 ha). Thus, the value of the choice of mangrove ecosystem is: Area of land $\mathrm{x}$ US $\$ \mathrm{x}$ Rupiah $=10 \mathrm{Km}^{2} \mathrm{x}$ US $\$ 1500 \mathrm{x} \mathrm{Rp}$ $13,350.00=\operatorname{Rp} 200,250,000.00$ per year.

\subsection{Assessment of economic benefits of total mangrove forest}

The total economic value of the mangrove ecosystem is the sum of the value of direct benefits, indirect benefits, and benefits of choice. Quantification of the benefits of mangrove forests as a whole shows that, the total benefit value of Rp.1.390.233.458,00 / year, where indirect benefits have more value High compared to other types of benefits with a percentage of $79.1 \%$. The total value of benefits can be seen in Table 1 .

Table 1. Total Economic Benefit Value of Mangrove Forest

\begin{tabular}{|c|l|l|l|}
\hline \multirow{2}{*}{ No. } & \multirow{2}{*}{ Type of Benefits } & Use Value & \multirow{2}{*}{$(\%)$} \\
\cline { 3 - 3 } & & \multicolumn{1}{|c|}{$(\mathbf{\% p} / \mathbf{y}$ )ars) } & \\
\hline 1. & Direct Use Value & $90,648,258$ & 6.5 \\
\hline 2. & Indirect Use Value & $1,099,335,000$ & 79.1 \\
\hline 3. & Option Value & $200,250,000$ & 14.4 \\
\hline & Total Economic Value & $1,390,233,258$ & 100.0 \\
\hline
\end{tabular}

\section{Conclusion}

Based on the results of research that has been done then it can be concluded as follows:

1. Utilization of mangrove resources in Baros hamlet that can be directly felt by the community, namely: fishery utilization (Scylla sp., Mugil sp., Macrones $s p$., Oreochromis) and utilization of mangrove seedlings.

2. Based on the research results obtained the total economic value of mangrove forests in Baros hamlet of Rp. 1,390,233,258 per year, calculated from direct benefits Rp. 90,648,258 per year, indirect benefit Rp. 1,099,335,000 per year and a choice of Rp.200.250.000 per year. 


\section{Acknowledgements}

We would like to thanks the Master Program of Environmental Science, School of Postgraduate Studies, Diponegoro University, Semarang for the knowledges and experiences. Also thanks to Dwi Ratmanto and KP2B for valuable information and supports for this paper.

\section{References}

1. AD. Setyawan, K. Winarno, Biodiversity, 7 (April): 159-63, (2006)

2. Gunarto. Conservation of Mangrove as Supporting Biological Resources of Coastal Fishery. (2004)

3. Pramudji. Oseana, XXV (2): 13-20, (2000)

4. H. Purnobasuki, Bul PSL, 25: 3-6, (2011)

5. Suthawan Sathirathai. Economic Valuation of Mangroves and the Roles of Local Communities in the Conservation of Natural Resources : Case Study of Surat Thani , South of Thailand. Research Reports. (1995)

6. WD. Kalitouw, Economic Valuation of Mangrove Forest In Tiwoho Village, Wori Subdistrict, North Minahasa District. J Univ Sam Ratulangi. (2015)
7. HJ. Ruitenbeek, Mangrove Management: An Economic Analysis of Management Options with a Focus on Bintuni Bay, Irian Jaya. Jakarta and Halifax; (1992)

8. B. Barbier, Valuing Environmental Functions: Tropical Wetlands Edward, 70 (2):155-73, (1994)

9. Center for Natural Resource Surveys. Guidelines for Preparation of Balance Sheets and Values of Coastal and Marine Natural Resources Economies. Cibinong: Bakosurtanal; (2005)

10. KP2B. Activity Profile of Community Based Mangrove Forest Development. Bantul; (2014)

11. Trialfhianty TI. Kondisi Ekosistem Mangrove Dusun Baros. (2013)

12. Decision of Bupati of Bantul Number 284 Year 2014 concerning Coastal Reserve Conservation Area, No. 284, (2014)

13. Ismi T. Economic Valuation of Mangrove Resource In Baros Coast Tirtohargo Village Sub-District of Kretek. Kawistara. (2014)

14. M.G.H.Kordi. Mangrove Ecosystem "Potential, Function and Management." Jakarta: PT Rineka Cipta; (2012) 